\title{
Trace fossils at the basal Upper Greensand (Albian, Cretaceous) unconformity surface in east Devon (south-west England) and the nature of the unconformity surface
}

Gallois, R.W. and Goldring, R. 2007. Trace fossils at the basal Upper Greensand (Albian, Cretaceous) unconformity surface in east Devon (south-west England) and the nature of the unconformity surface. Proceedings of the Geologists' Association, Vol. 118, 265-275.

\author{
ABSTRACT \\ Along the east Devon coast the early Cretaceous Upper Greensand Formation rests \\ unconformably on bioturbated firmground and hardground surfaces on mid Triassic to \\ early Jurassic rocks (Mercia Mudstone Group to Lias Group). The classification and \\ interpretation of the burrows and borings preserved on and beneath these surfaces are \\ discussed, and compared with those from similar bioturbated surfaces elsewhere in \\ Europe. In east Devon, the nature of the preservation of these trace fossils is dependent not \\ only on the nature of the substrate but also on that of the infilling materials. These range \\ from poorly defined, irregular infillings composed of pebbly mudstone to well-defined \\ casts of cemented fine-grained sandstone that preserve detailed external ornaments. The \\ most prominent trace fossils recorded are regularly spaced, flask-shaped Gastrochaenolites \\ ornatus Kelly \& Bromley that were produced by an as yet unidentified bivalve that rotated \\ during penetration. At Branscombe, where the Upper Greensand rests on Triassic \\ mudstones, many of the crypts are ellipsoidal to subhemispheroidal in cross-section. Their \\ producer(s) are also enigmatic. Some infillings contain fragments of Myopholas or \\ Girardotia, bivalves that rotate during penetration of soft to firm substrates. These \\ burrows were probably initiated above the unconformity surface and extended down into \\ an already perforated and softened mudstone surface. A few burrows may be due to a \\ burrowing coelenterate. Bioturbation at the sub-Albian unconformity is ubiquitous in \\ southern and eastern England, and indicates that the erosion surface was available for \\ colonisation for a considerable period of time.
}

\section{INTRODUCTION}

The Cretaceous rocks of south-west England are noted for their facies changes, omission surfaces and unconformities (Hancock, 1969). Westwards from the almost complete late Jurassic and Cretaceous successions of the east Dorset coast between Lulworth and Swanage, successive formations are overstepped by the Albian Gault Formation until it 
rests on the early Jurassic Lias Group at Charmouth. Westwards from there, the Gault passes laterally into Upper Greensand facies and the latter formation comes to rest on progressively older rocks. At its most westerly outcrop in Devon, on the Haldon Hills, the Upper Greensand rests on Permian strata (Hamblin \& Wood, 1976).

The unconformity surface is poorly exposed on both the Devon and Dorset coasts. Extensive landslips generated by shear failures close to the base of the Gault in Dorset and along thin mudstone beds close to the base of the Upper Greensand in Devon, commonly obscure the junction. In addition, decalcification of the Upper Greensand has produced large amounts of sandy Head that locally cover much of the underlying succession. Wherever it has been recorded, the unconformity surface at the base of the Gault/Upper Greensand is sharp and essentially planar with only minor erosional irregularities, such as that at Locality 2 (see below) where it cuts out $0.4 \mathrm{~m}$ of the late Triassic 'White Lias' (Langport Member of the Lilstock Formation) within a distance of $5 \mathrm{~m}$. The basal bed above the sub-Albian unconformity is pebbly at almost all localities on the south coast, mostly with numerous well-rounded quartzitic pebbles and angular clasts of the immediately underlying formation. Good examples occur in east Dorset (Arkell, 1947) and at Charmouth (Woodward \& Ussher, 1911) in west Dorset.

The sedimentology and palaeontology of the Upper Greensand in Devon indicate deposition in shallow, mostly sub-tidal marine environments. The sub-Albian unconformity surface locally preserves traces of the animals that colonised the underlying lithified strata as the sea transgressed westwards over the former land surface. The objectives of this paper are to record the nature of this surface in east Devon and to describe the bioturbation structures. These range from indistinct traces to well-defined cavities (crypts) that are infilled with cemented sediment (crypt casts). There are, however, problems of terminology relating to the use of the terms boring and burrow that need to be clarified first. 


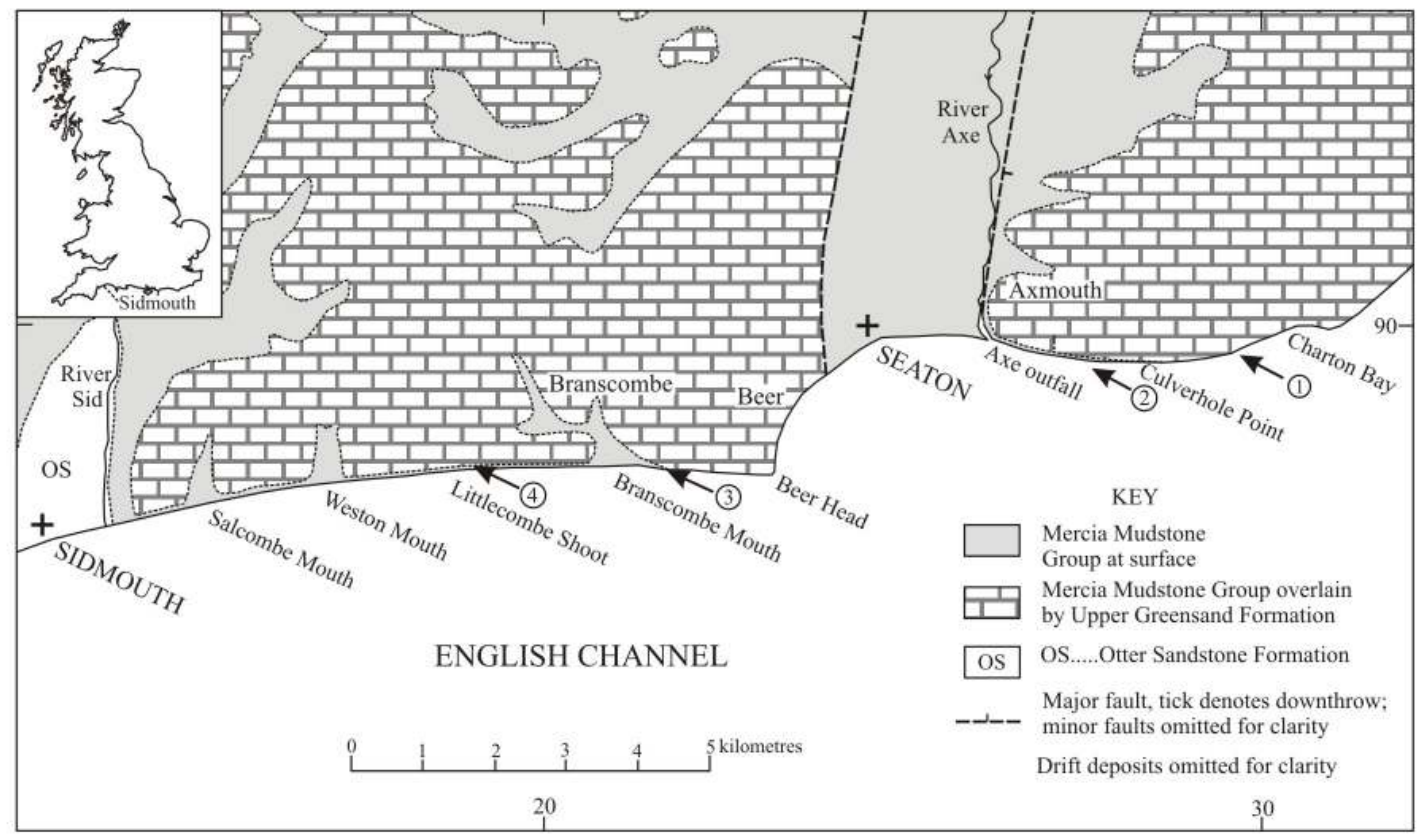

Figure 1. Geological sketch map showing the geographical positions of the four tracefossil localities referred to in the text.

\section{TERMINOLOGY}

Trace fossil borings associated with lithified substrates (hardgrounds) have been referred to several ichnogenera (Häntzschel, 1975). Different names have been applied to burrows made by bivalves and other organisms in less lithified surfaces that have been variously referred to as 'soft', 'loose', 'firm' or 'stiff' (e.g. Hanken et al., 2001). However, although individual ichnotaxa are mostly morphologically well-described, the distinction between borings and burrows is not clearly defined (e.g. Savazzi, 1999) and is commonly taken at an arbitrary point in a continuum of forms. In addition, the excavation processes involved by bivalve molluscs have commonly been inadequately considered with respect to the substrate and the morphology of the fossil material. For example, Evans (1970) used the terms boring and burrow more or less interchangeably for the crypts of Penitella penita (Conrad), Zirfaea crispata (Linné) and other bivalves. However, the distinction has also been used to estimate the degree of lithification of omission surfaces (e.g. Tucker \& Wright, 1990), and is therefore sedimentologically important.

There continues in some cases to be misunderstanding of how and where fossil bivalve crypts are formed. For example, Kelly \& Bromley (1984) described the common ichnogenus Gastrochaenolites as "clavate borings in lithified substrates", and it has 
subsequently been interpreted solely as an indicator of hardground penetration. However, many modern bivalves can penetrate a wide range of lithologies with markedly different hardnesses. For example, the common piddock Pholas dactylus (Linné) of north-west European shores excavates crypts in soft to hard mudstones (including the Mercia Mudstone of the east Devon coast), chalks, soft sandstones, peats and wood (Röder, 1977). In a study of the mechanisms used by modern bivalves during protrusion into substrates, Savazzi (1999) concluded that they use a combination of muscular movements and morphological adaptations of the shell, and in some instances chemical processes, to effect penetration into a range of substrates of varying hardnesses and chemistries. By utilising three-dimensional muscular movements and the muscular foot, the boring animal rotates to produce a crypt that is circular in cross-section.

Burrowing by bivalves into soft to firm sediment is performed either by hydraulic (water-jet) action (Savazzi, 1990) or, more commonly, by probing with the foot about a vertical axis combined with relaxation of the shell's adductor and diductor muscles to anchor the valves to the sides of the burrow (Trueman \& Ansell, 1969). The latter process takes advantage of the hydraulic properties (thixotropy and dilatency) and/or degree of consolidation of substrates that range from 'fluid' to stiff. The typical bivalve burrow is elliptical in cross-section, following the form of the shell. It should be noted, however, that burrowing coelenterates that use a similar mechanism have a circular body plan and produce burrows that are circular in plan.

In the course of their evolution, bivalves have developed the ability to penetrate fully lithified substrates. The evolutionary processes by which this was achieved have not been charted because the body fossil taxa involved are incompletely known. Savazzi (1999) proposed the term borehole as a compromise to include all bivalve borings and burrows, but its long-established use in civil engineering makes it inappropriate for palaeontological use. 
Gallois, R. W. and Goldring, R. 2007. Albian (Cretaceous) trace fossils. PGA, 118, 265-275.

Criteria that can be used to distinguish between fossil bivalve borings and burrows include:

(i) Most borings are circular in cross section and many burrows are elliptical except in long siphonate forms.

(ii) Borings typically cut cleanly through all but the most impenetrable (for hardness or chemical reasons) material and are diverted only to avoid adjacent borings. They cut across bioclasts and matrix alike, although particularly hard or insoluble grains may stand proud.

(iii) The denticulate ribbing of some boring bivalves may impart scratch marks (bioglyphs) on the margins of their crypts: preservation usually depends on the hardness of the substrate (well-illustrated by Röder, 1977). Bioglyphs are rarely formed by burrowing bivalves.

(iv) Some burrowing bivalves are able to move upwards with sediment aggradation, a process not possible for boring bivalves.

Mikuláš et al. (2003), working on firmgrounds at the sub-Cretaceous unconformity in the Czech Republic, have suggested that crypts should be defined on the basis of morphology (which reflects the processes of substrate penetration) and not on the inferred degree of substrate lithification.

For convenience, boring is used in the present work for crypts that are circular in crosssection (mostly found in firm to hard substrates) and burrow for crypts that are oval in cross-section (mostly found in soft to firm substrates).

\section{LOCALITIES}

The unconformity surface at the base of the Gault and Upper Greensand has been observed at several localities on the east Devon and west Dorset coast during the present work, but only four (all in Devon) have revealed an extensively burrowed surface (Fig. 1). At each of these, the top 100 to $150 \mathrm{~mm}$ of the sub-Cretaceous stratigraphy is extensively penetrated, in some cases spectacularly so, by more than one phase of bioturbation. The subunconformity surface at these localities at the time of penetration appears to have varied from firm to stiff on the mudstones of the Mercia Mudstone Group to hard on the 'White 
Lias' and Shales-with-Beef limestones (Fig. 2). All four sites contain the distinctive flaskshaped crypts of Gastrochaenolites and the infillings of numerous less well-defined crypts and gallery complexes.
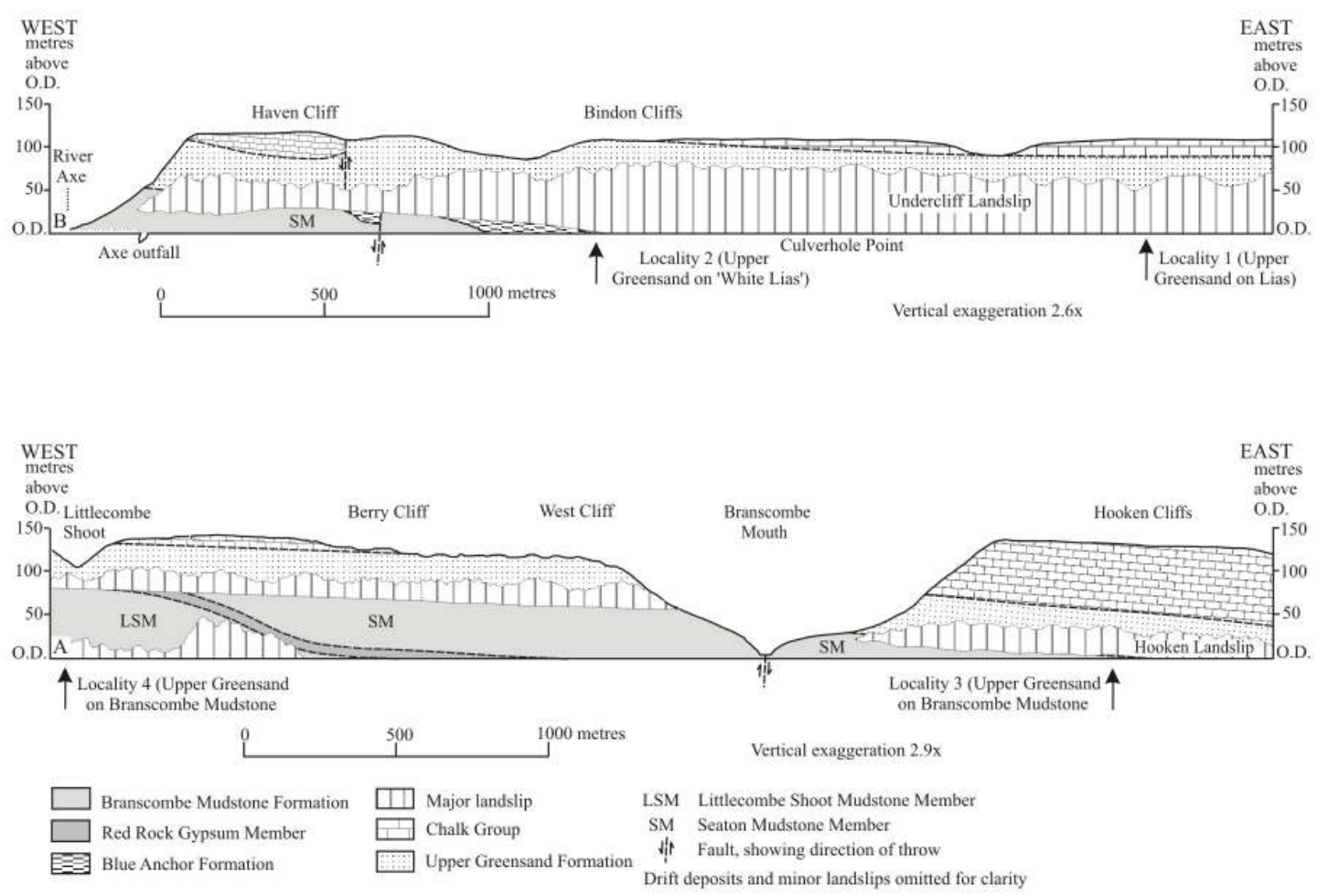

Figure 2. Geological sketch sections of the coastal exposures between A: Localities 1 and 2 (adjacent to Culverhole Point). B: Localities 3 (Branscombe Mouth) and 4 (Littlecombe Shoot) (after Gallois, 2001).

Details of the sites, from east to west, are as follows:

Locality 1: disturbed outcrops [SY 293 896] on the foreshore at the foot of the Undercliff Landslip, 500m W of Charton Bay, expose muddy sand infills in the top of an $0.25 \mathrm{~m}-$ thick limestone bed in the Shales-with-Beef Member (Charmouth Mudstone Formation, Lias Group) beneath a veneer of Upper Greensand. Substrate: (at time of colonisation): hard calcilutite ('cementstone').

Locality 2: the top surface of the 'White Lias' in low cliffs [SY 273 894], $500 \mathrm{~m} \mathrm{~W}$ of Culverhole Point, has numerous crypts filled with gritty, sandy mudstone (Fig. 3). The bored surface varies laterally due to an irregular westerly overstep of the Upper Greensand across the 'White Lias'. The limestones range from hard, laminated and micritic to very hard, recrystallised and nodular, but only the former appear to be extensively bioturbated. Lamination is evident on some of the crypt surfaces, but bioglyphs or sculpture that might 
have resulted from the action of the producer have not been observed. The basal bed of the Upper Greensand, including the sediment infilling the crypts, is a clayey glauconitic sand with rounded to angular clasts of Seaton Mudstone Member (Branscombe Mudstone Formation, Mercia Mudstone Group), abundant small pellets of clay ironstone and common fragments of the Albian oyster 'Ostrea' papyracea Sinzow. In contrast to Locality 3 , the infills and the overlying sediment are not markedly secondarily bioturbated. Substrate: hard, fine-grained limestones.
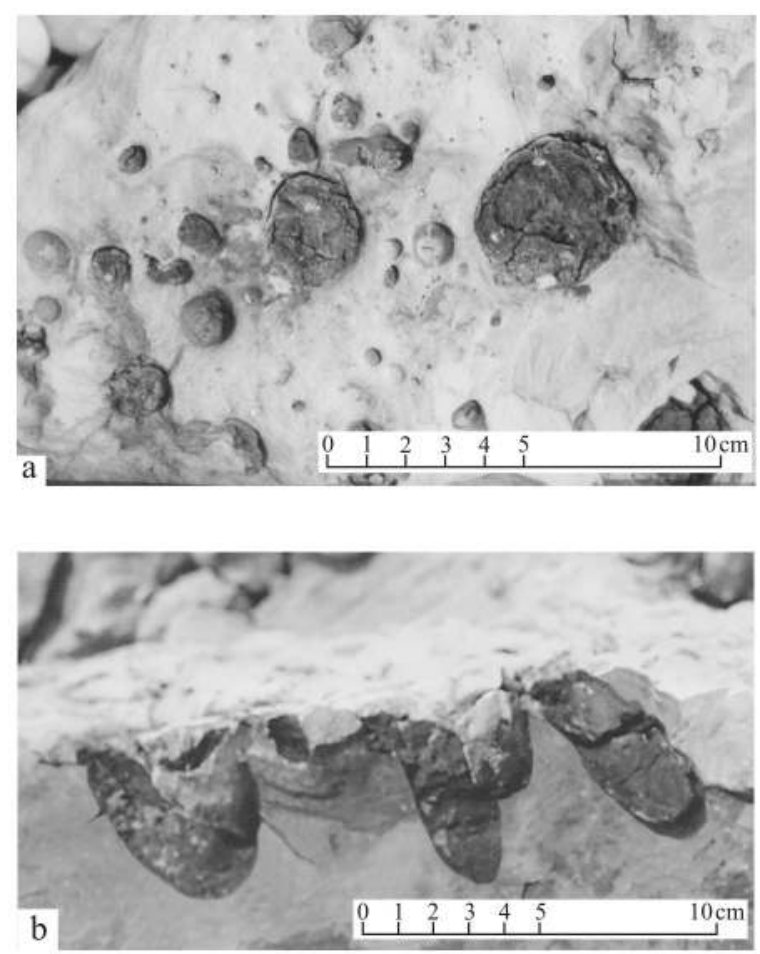

Figure 3. Gastrochaenolites ornatus Kelly \& Bromley at the unconformity surface between the 'White Lias' and Upper Greensand at Locality 2: (a) plan view looking down on the unconformity surface and (b) side view. The crypts are infilled with gritty, sandy mudstone, and truncated at the unconformity surface.

Locality 3: a degraded slope [SY 210 881] at the foot of the Hooken Landslip, 300m E of Branscombe Mouth, exposes the unconformable junction of the Seaton Mudstone and the Upper Greensand. Permission was obtained from the landowner to expose an area of about $2 \mathrm{~m}$ x $0.5 \mathrm{~m}$. This revealed several layers of stony, sandy Head deposit derived from the overlying landslip above 60 to $100 \mathrm{~mm}$ of in situ Upper Greensand that rested on an extensively bioturbated erosion surface cut in red silty mudstones (Fig. 4). The basal bed of the Upper Greensand consists of a complexly bioturbated dark, slightly greenish grey, glauconitic fine-grained sand with abundant (locally up to $50 \%$ by volume) angular clasts 
of softened red mudstone up to a few centimetres across, and rare impressions of possible ostreid bivalves. Many of the clasts are perforated by sand-filled burrows, but it is not clear to what extent they pre- or post-date their incorporation into the Upper Greensand. Some are burrowed on all sides and certainly post-date it.

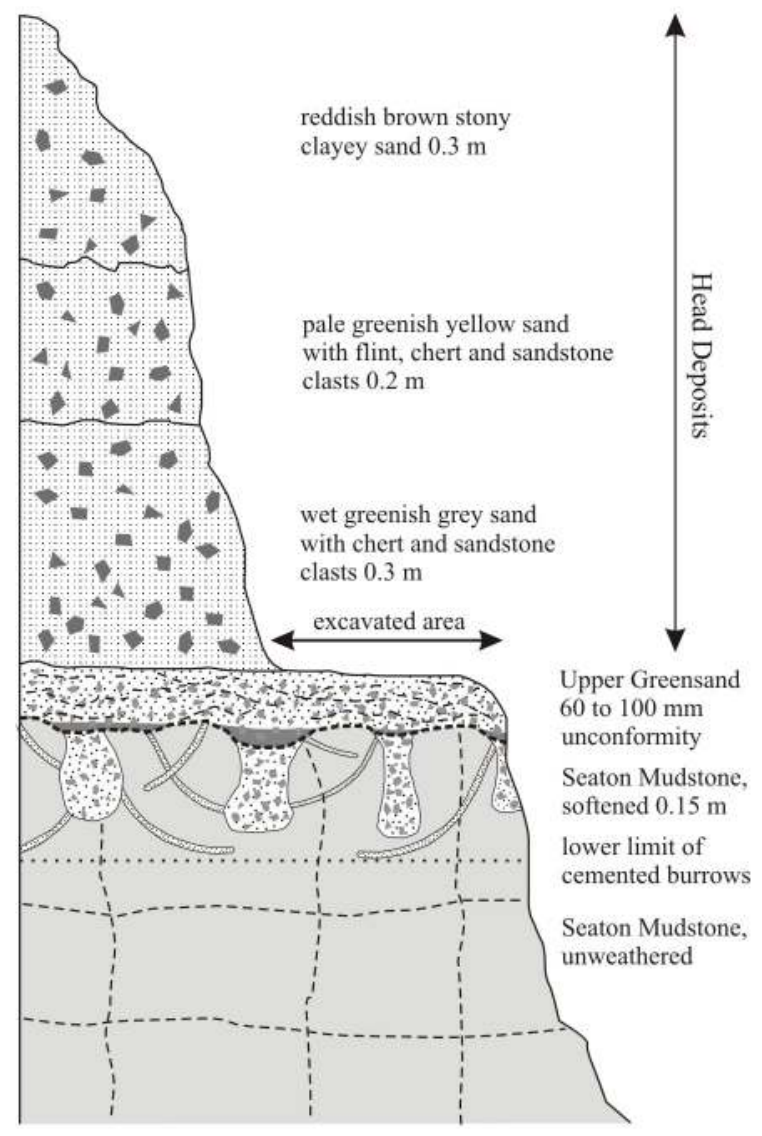

Figure 4. Diagrammatic section of the unconformity and bioturbated surface at Locality 3.

The Seaton Mudstone beneath the unconformity is well-jointed and largely unweathered. Infilled crypts descend from the unconformity surface and common, mostly low-angle, linear burrow-fills extend to about $150 \mathrm{~mm}$ below it. The unconformity surface is uneven, with shallow (up to 3-mm deep) depressions at a 150- to $200 \mathrm{~mm}$ spacing that are filled with grey clay (Fig.4). Many of the crypt infillings are calcareously cemented fine-grained sand not dissimilar to industrial moulding sand. In some cases this has preserved details of ornaments on the crypt wall. Similar ornaments may have been present at the other localities described here, but have not been preserved by less suitable infill materials. The depressions seem to coincide with the positions of the two principal types of trace fossil, both of which include examples that extend upward above the unconformity surface. In these, the upper few centimetres of the infilling casts and the surrounding 
Upper Greensand matrix are so highly bioturbated that the top of the casts is indeterminate and it is uncertain how much is missing. The bioturbation clearly post-dates the formation of the casts.

Substrate: weakly cemented and lithified mudstone.

Locality 4: a cliff-top exposure [SY 182 882] at Littlecombe Shoot exposes the Upper Greensand resting on red silty mudstone of the Littlecombe Mudstone Member (Branscombe Mudstone Formation, Mercia Mudstone Group). The unconformity surface is extensively bioturbated, but the infillings are uncemented, gritty, sandy clay that has preserved little crypt structure. Another outcrop [SY 183 882] of the unconformity (100m east) shows extensive bioturbation within the top $250 \mathrm{~mm}$ of the Littlecombe Mudstone in which only poorly defined linear burrows are preserved as soft, sandy clay infills. Substrate: weakly cemented and lithified mudstone.

\section{ICHNOLOGY}

\section{Bioturbation structures and their interpretation}

Several types of crypt and crypt cast are present at all four localities, together with common linear traces. For descriptive purposes they are grouped here into two types. The Type I crypts have similar forms and are thought to have been produced by the same animal. The Type II crypts include a range of morphologies that were probably made by more than one type of producer. Most of the material collected consists of weakly cemented infillings of burrows and borings that form casts of entire crypts (Figs 5-7). A few specimens preserve impressions of part of the external shell of the producer (or, possibly, that of a secondary crypt coloniser). Specimens referred to in the text are deposited in the collections of the Natural History Museum, London (Nos. NHM TF 156168).

Type I casts (Fig. 6a) from Locality 2, and casts of identical form from Locality 3, are flask-shaped and circular in cross-section with a hemispherical base. At Locality 2, the crypts range from $90 \mathrm{~mm}$ deep and $40 \mathrm{~mm}$ in diameter to less than $10 \mathrm{~mm}$ in depth, and represent several generations. The smaller crypts penetrate the unconformity surface and 
the margins of some of the larger crypts, indicating that the larger crypts were empty at the time of secondary colonisation.

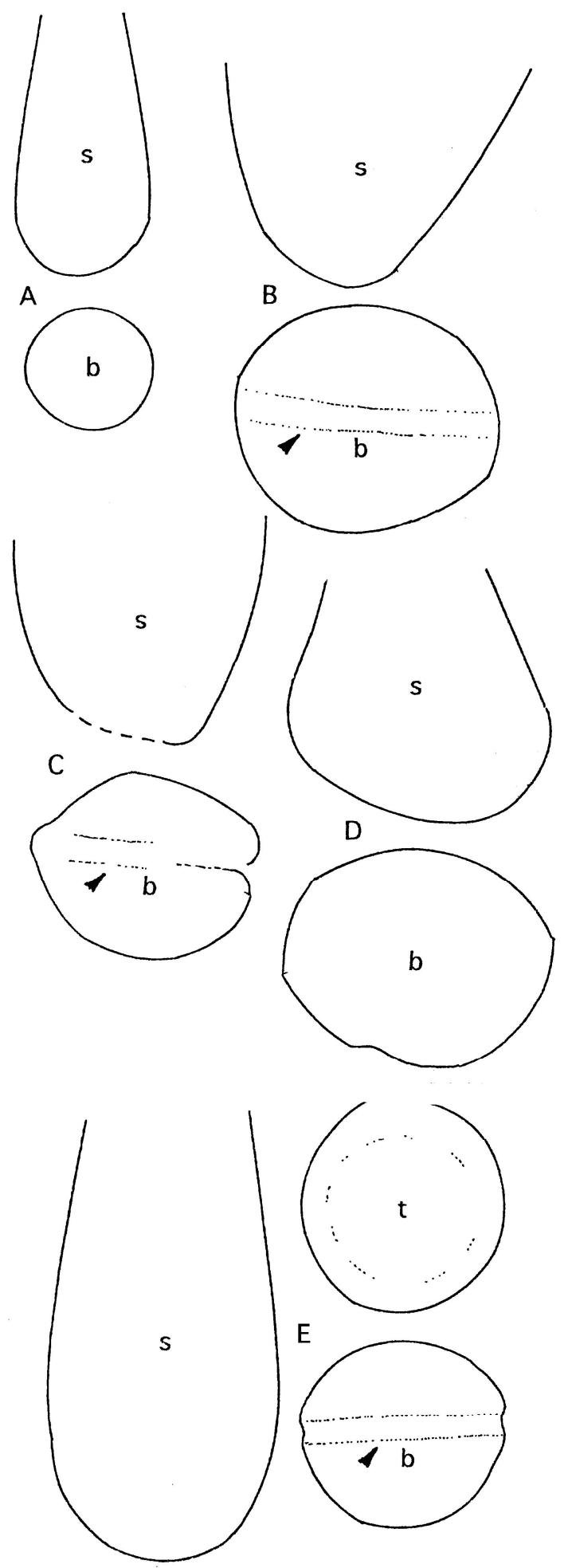

Figure 5. Side (s), top (t) and basal (b) profiles of five of the more complete casts. Groove at base indicated (arrowed) where present. All x 0.5. Type I cast: A (TF 156); Type II casts: B (TF 160); C (TF 168); D (TF 158); E (TF 167, possible Type I cast). All specimens from Locality 3. 
The orientation of the small crypts is variable. Most appear to be normal to the unconformity surface, but others are highly oblique or normal to a larger crypt margin. The maximum diameter of the larger crypts $(75 \mathrm{~mm})$ is about three-quarters of their depth, and about two thirds greater than the diameter at the top (as preserved). At Locality 2, the outer surfaces of the crypt casts in the 'White Lias' limestones are smooth (Fig. 3). Some of those at Locality 3 (Fig. 6a) show a faint transverse fine ratchetting around part of the base, and longitudinal ridges which tend towards a sigmoidal form towards the base. Their outer surfaces show numerous filled burrows, 1 to $2 \mathrm{~mm}$ in diameter (see below).
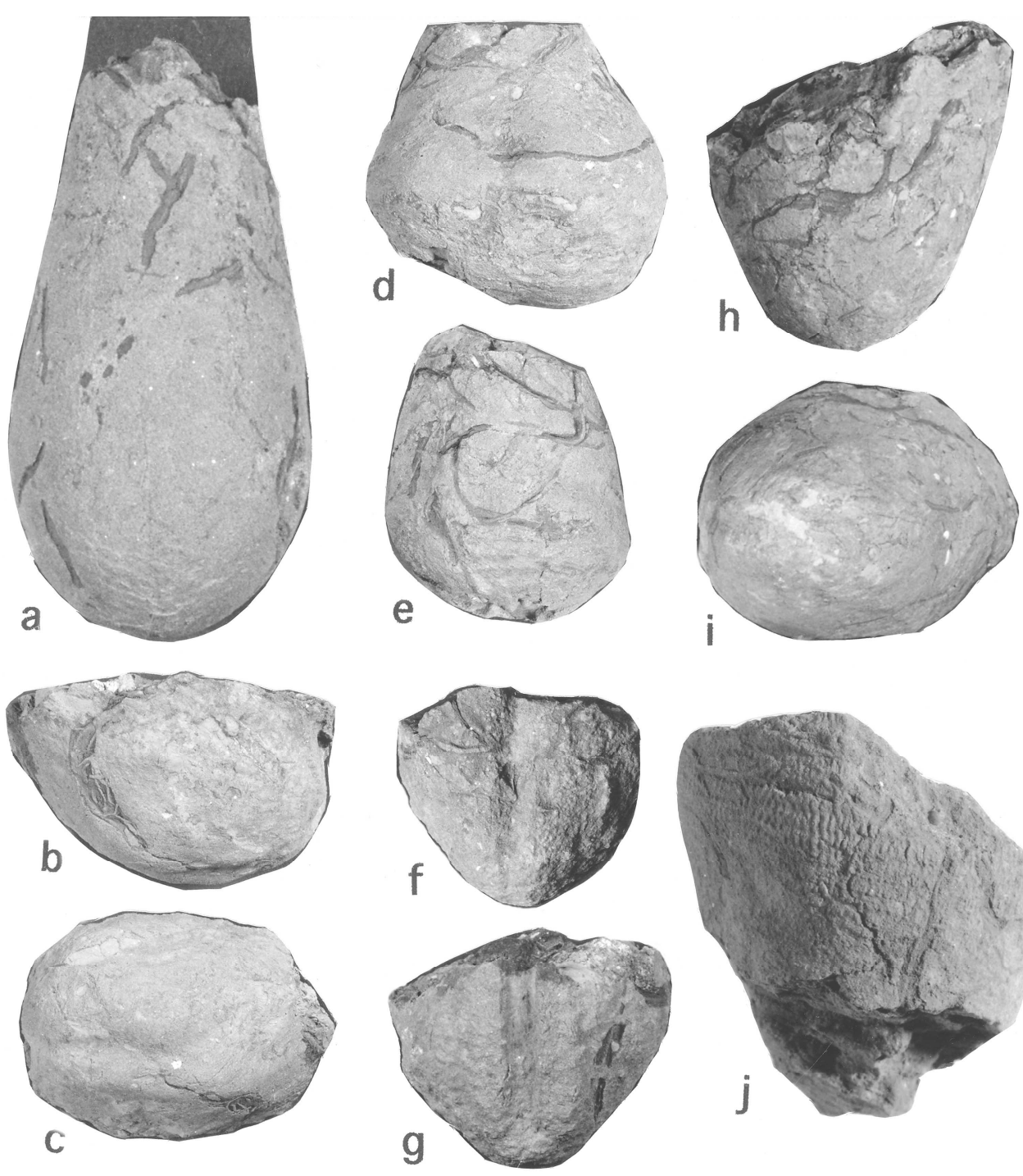

Figure 6. (a) Type I cast, G. ornatus, side view, x 1, (TF 156), . (b-j) Type II casts, (b,c) side and basal views, x 0.5 (TF 157), (d, e) side views of dumbbell-like cast possibly produced by bivalve action, x 0.5 (TF 158), (f, g) side views of cast with deep groove, of possible bivalve origin, x 0.5 (TF 162), (h, i) side and basal views, x 0.5 (TF 160), (j) side view of specimen with Conostichus-like 'ornament', x 1.5 (TF 161). All specimens from Locality 3. 
Some of the casts from Locality 3 fit neatly within the crypts at Locality 2 and are presumed therefore to be attributable to the same taxon. The sedimentology of the limestones at Locality 2 (laminated and nodular limestones separated by strongly lithified hardgrounds that are incorporated into penecontemporaneous slumped beds as angular clasts) indicates that the substrate was fully lithified at the time of the Albian transgression.

The Type I crypts and crypt casts from localities 2 and 3 are identified as Gastrochaenolites ornatus Kelly \& Bromley and can be attributed to bivalve activity. They are similar in form to the borings of Pholas dactylus that are conspicuous in the Mercia Mudstone on the present-day rock platforms close to both sites. Röder (1977) sampled some of these localities for his analysis of the functional morphology of boring bivalves. No body fossil material has been recorded in association with the Type 1 crypts, and they could have been produced by any one of several Cretaceous pholadid bivalve species.

Type II casts from Locality 3 display a wide range of forms that resulted from more than one type of coloniser. Our collection is represented by incomplete and fragmentary material that has been truncated, as well as being secondarily bioturbated (see below). Several are elliptical in transverse cross-section, subhemispheroidal and roughly boat shaped (Fig. 6h). Some have an outer marginal zone up to $5 \mathrm{~mm}$ wide that contains clean sand and angular clasts of Seaton Mudstone. The clasts do not project into the main section of the cast and are commonly flattened and curved along the inner margin, suggesting that they were plastic at the time of their incorporation into the crypts. Dissection and removal of this outer layer from one of the casts (Fig. 7a) revealed several curved ridges similar to those that are produced when the anterior external surface of bivalves such as Myopholas is pressed against plastic sediment. Similar ribbing is preserved as ridges on some of the other casts (e.g. Fig. 6d,e). This suggests an association with ?Myopholas, either as the burrow former or as a secondary coloniser. Examples of Myopholas in the collections of the Natural History Museum (London), although relatively small, include loose specimens from the Kimmeridge Clay, and specimens in their crypts in sandstone from the Upper Jurassic of the Ukraine. Myopholas is known from the Albian 
of France (Cox et al., 1969, fig. F20, 1c) but has not been recorded from the Cretaceous of the UK. Morphologically similar Girardotia is known from the Kimmeridge Clay and Lower Cretaceous of England and is the more likely constructor in the Upper Greensand (S. R. A. Kelly, pers. comm.).

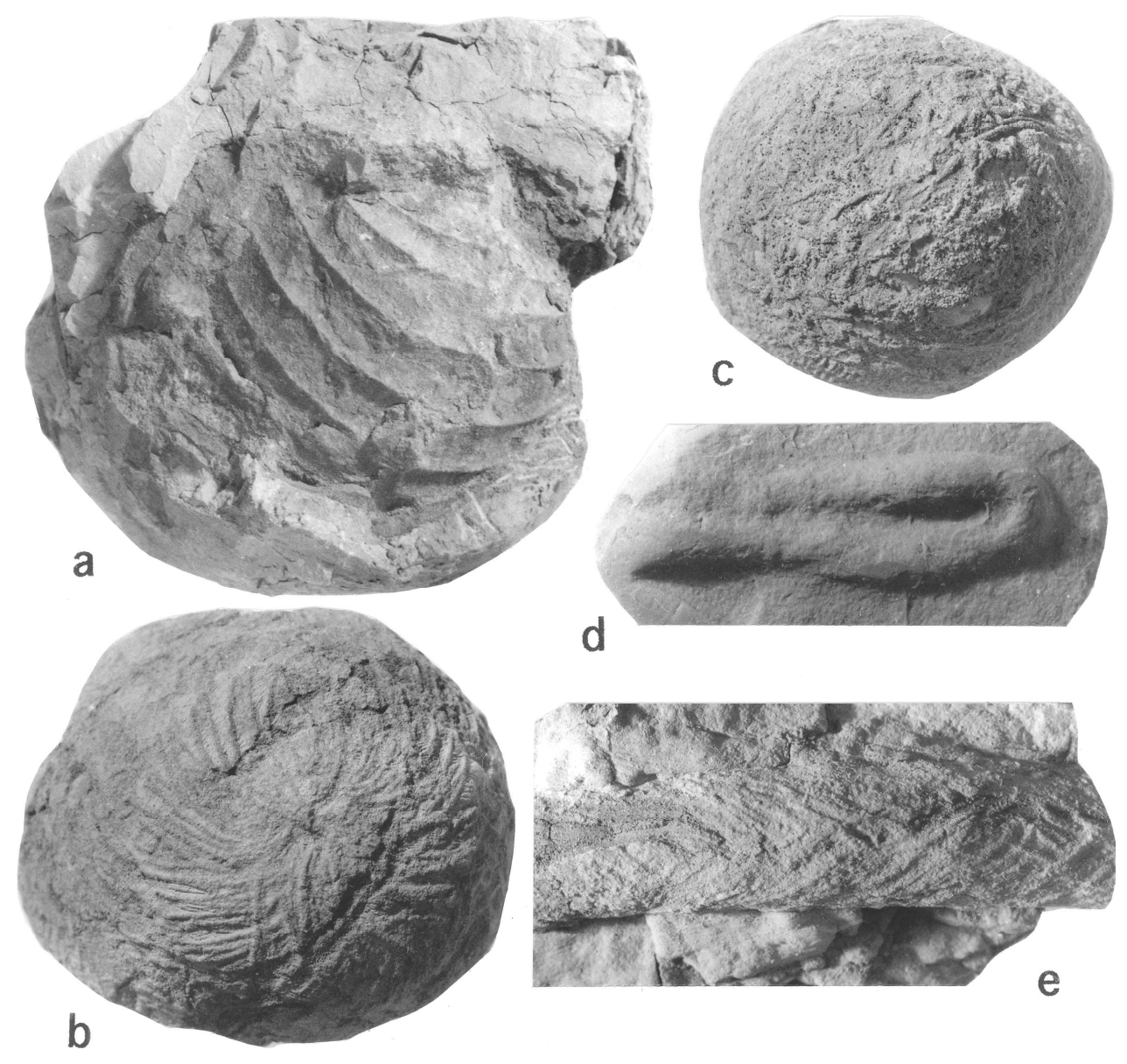

Figure 7. (a) Side view, with Myopholas-like ribbing on broken cast (TF 166); (b) basal view with spiral bioglyphs, $x 1.5$ (TF 159); (c) basal view with secondary burrows, $\mathrm{x} 1$ (TF 163); (d) Plasticene pull of field specimen of sub-horizontal U-shaped burrow, $x$ 1.5 (TF 165); (e) burrow fill with casts of bioglyphs suggestive of crustacean origin $x$ 1.5, (TF 164). Specimen $\mathbf{d}$ from Locality 2, others from Locality 3.

Several casts have a shallow groove (Figs. $5 b, c, e ; 6 c, f, g)$ that runs around the vertical axis. These have a width of about $7 \mathrm{~mm}$ and a maximum depth of $2 \mathrm{~mm}$ at their bases, shallowing upwards on both sides. One specimen (Fig. 6f,g) has a groove that deepens and narrows upwards from $7 \mathrm{~mm}$ width at the base to $3 \mathrm{~mm}$ at the top. These grooves could be explained as the mould of sediment that had entered between the margin of the crypt and the valves, and partly into the anterior gape to the shell. In the bulbous, sack-like form 
(Figs. 6d,e) two individuals may have interacted to produce a dumbbell-like cast with a weak groove on one side.

Other markings are undoubtedly due to irregular secondary burrowing (see below), but in specimen TF159 (Fig. 7b) they form a subspiral pattern of ridges that closely resemble those produced on the base of the borings made by Pholas dactylus (Röder, 1977, figs. 11, 12) and on the bases of several specimens described and figured by Mikuláš et al. (2003) and attributed to cutting by Myopholas.

Two casts (Fig. 6j, 7c) with a more circular cross-section, bear irregularly spaced (approx. $3 \mathrm{~mm}$ ) sub-concentric ridges and superimposed oblique, fine longitudinal striations (1 mm spacing) on their outer surfaces. The striations intersect the ridges to produce a fine pustular ornament similar to that of some solitary corals. This ornament is obscured by secondary burrows in one specimen (Fig.7c). The fine longitudinal striations and concentric ribbing resemble those of Conostichus ornatus Lesquereux and $C$. wycherlyi (King). Conostichus is one of a group of plug-shaped and conical trace fossils reviewed by Pemberton et al. (1988), and variously attributed to the action of plant roots, sponges, the dwelling burrows of actinians (sea anemones) and the casts of body fossils of medusoids (jellyfish and hydrozoans). Röder (1977) illustrated scratch marks on the crypt margins of Pholas dactylus borings in sandstones, but these do not display fine longitudinal markings. The specimens from Locality 3 that have an ellipsoidal form and an anterior groove do not match the body form of any known coelenterate. However, those with a fine ornament and a more circular cross-section, are tentatively attributed here to a burrowing coelenterate such as a sea pen.

Taxonomic attribution of the Type II casts is difficult because of their variation in form. We tentatively refer most of them to Gastrochaenolites isp. The problem is akin to the variation Hanken et al. (2001) observed due to retrusive and protrusive movements of the burrower Panopea faujasi Ménard de la Groye in the Pliocene of Rhodes. However, we note that Bromley \& Asgaard (1993) were faced with a similar problem with late Pliocene borings into Mesozoic limestone on Rhodes. Although some distinctive Gastrochaenolites were present, the authors erected a new ichnotaxon Phrixichnus for less regular borings, 
Gallois, R. W. and Goldring, R. 2007. Albian (Cretaceous) trace fossils. PGA, 118, 265-275.

for which a bivalve action was also suggested. As an example of the wide range of forms that have been attributed to Gastrochaenolites, Donovan (2002) proposed a new ichnotaxon G. pickerilli for small clavate borings into Pleistocene specimens of the conch Strombus gigas (Linné). These show meniscae on one side demonstrating a lateral shift by the crypt maker.

\section{Other trace fossils}

At Locality 2, there are unbranched, straight to curved, filled tunnels 2 to $3 \mathrm{~mm}$ in diameter, mostly penetrating to 20 to $30 \mathrm{~mm}$ below the unconformity surface and following a course more or less parallel to the surface. No bioglyphs were observed, and paired openings were not evident. One example (Fig. 7d) has a sub-horizontal, U-shaped form suggestive of the boring Caulostrepsis Clarke. Three additional types of trace fossils were recorded at Locality 3 :

(i) cylindrical (commonly compressed to an ovoid cross section), straight to slightly curved, unbranched burrows, of two sizes, c. $2 \mathrm{~mm}$ and 8 to $12 \mathrm{~mm}$ diameter (Fig. 7e), penetrate the Seaton Mudstone. As with the larger crypt casts, the fill comprises muddy sand with fragments of Seaton Mudstone. The outsides of the larger diameter casts carry the impressions of slender scratches (bioglyphs) $1 \mathrm{~mm}$ in width. These are irregularly grouped and criss-cross the burrow margin, a feature that is characteristic of Glyphichnus harefieldensis (White) (Bromley \& Goldring 1992; Bromley, 1996, fig.8.7). They represent the passive infill of open burrows excavated in the Seaton Mudstone by a crustacean, and indicate that the substrate was a firmground rather than a hardground at that time. It is uncertain whether this type of burrow cuts, or is cut by, the larger crypts. Secondary burrows were not recorded.

(ii) the crypt casts and overlying sediment are pervaded by slender linear, unbranched, 1-mm-diameter burrows (Planolites isp.) infilled with sand or muddy, silty sand. These are particularly conspicuous at the margin of most of the casts. A similar type of burrow was referred by Mikuláš et al. (2003) to Arachnostega Bertling. 
(iii) larger (2- to 3-mm diameter) mud-filled burrows (possibly branching) are present at the margin of several casts (Figs. 6a,e,h). In some instances they loop, arenicolitid-like, and may be secondarily burrowed by small sand-filled burrows.

(iv) the top of specimen TF 158 carries the cross-section of a small Diplocraterion within a red mudstone clast that is normal to the cast. Burrowing probably postdates the infilling of the crypt.

\section{DISCUSSION}

The Mercia Mudstone outcrops on the wave-cut platform in east Devon form hard surfaces that are encrusted by the gastropod Patella (limpet) and the colonial tube-worm Sabellaria ('sand-mason'), and bored by bivalve Pholas dactylus and the polychaete worm Polydora. There is no reason to believe that the Mercia Mudstone would have been markedly softer or harder at the time of the Cretaceous transgression. Locally, the present-day Pholas dactylus borings are so closely spaced that the rock readily crumbles and is removed by storm action. It is likely that while the Type I Gastrochaenolites borings were cut directly into the unconformity surface, some of the other, less regular crypts, were formed by organisms that irregularly penetrated unlithified sediment that had accumulated a few centimetres above the unconformity surface, and is no longer preserved. These crypts extended down into the already weakened mudstone below the unconformity surface. The only field evidence suggestive of this interpretation is that the Type II casts are invariably truncated. Specimen TF 167 (Fig. 5e, possibly a Type I cast) is particularly deep, suggesting initiation from a level well above the unconformity surface.

Mikuláš et al. (2003) concluded that borings in firmgrounds at the sub-Cretaceous unconformity surface and intra-Cretaceous omission surfaces in the Prague area were cut into substrates with a wide range of hardnesses. They did not find a correlation between the shapes of casts and inferred substrates, but most of the casts were collected loose from deeply weathered rocks.

The distinction between small secondary burrow fills and bioglyphs is not always obvious. Mikuláš et al. (2003) were also faced with this problem, and noted that some 
scratches were probably made by arthropod appendages. The frequency of the spiral markings on the base of the Czech material points to a bivalve origin, but closely similar patterns described by Uchman \& Wetzel (1999) from the Upper Cretaceous flysch of Switzerland were interpreted by them as an aberrant form of Chondrites. The producer of their material was probably confined within a shell, which was subsequently dissolved. The small secondary burrows referred to as Planolites in this account match the description by Jensen \& Atkinson, (2001) of "barrier prospecting traces". These are made by organisms that encounter a 'hostile' substrate, in this case the undisturbed mudstone that forms the crypt margin, after passing through the crypt infill at a time when it was still uncemented.

A noticeable feature of the distribution of the casts at Locality 3 is their even spacing. Similar distributions have been noted by Snedden (1991), who observed conical casts 30$50 \mathrm{~cm}$ in diameter with a remarkable uniformity of spacing of about $90 \mathrm{~cm}$, and by Buck \& Goldring (2000) who recorded an even spacing of Conichnus (15 cm diameter) in the Globigerina Limestone (Miocene) of the Maltese Islands. Even spacing has been described and reviewed with particular reference to trace fossils by Pemberton \& Frey (1984). It provides an indication of the areal extent required by an organism for feeding from the water column, either by filtering or feeding on micro-organisms. None of the crypt casts at Locality 2 were sufficiently close to produce a distorted form. The sack-like cast (Figs. $6 \mathrm{~d}, \mathrm{e})$ may have resulted from two individuals abutting, but none of the specimens display a shift in penetration direction that might indicate avoidance.

\section{REGIONAL OVERVIEW}

The overstep of Albian sediments (Upper Greensand and correlative formations) onto Permian to Lower Cretaceous sediments in eastern and southern England is the most widespread in a succession of transgressions in the Cretaceous. Extensively bioturbated sub-Albian surfaces have been recorded throughout the region including Norfolk (Carstone on Sandringham Sands: Gallois, 1993), Cambridgeshire (Gault on Corallian Beds: Worssam \& Taylor, 1969), Oxfordshire (Gault on Upper Jurassic to Lower Cretaceous: 
Gallois, R. W. and Goldring, R. 2007. Albian (Cretaceous) trace fossils. PGA, 118, 265-275.

Pocock, 1926), Wiltshire (Upper Greensand on Kimmeridge Clay: Hesselbo et al. 1990) and the Isle of Wight (Gault on Lower Cretaceous: White, 1921). In east Dorset (Gault on Jurassic and Lower Cretaceous rocks: Arkell, 1947), the junction is invariably overlain by a thin bed of quartz and lydite pebbles. Our observations support the view that the subAlbian unconformity surface is not only a regionally significant erosion surface, but one that was available for marine colonisation for a considerable period after it had been cut. Mikuláš et al. $(2002,2003)$ came to a similar conclusion with respect to the subCretaceous unconformity in the Prague region.

\section{SUMMARY AND CONCLUSIONS}

The nature of the strongly bioturbated unconformity surface at the base of the Cretaceous (Albian) Upper Greensand Formation is described from sections along the east Devon coast. The unconformity surface at the time of penetration varied from firm to stiff on the mudstones of the Mercia Mudstone to hard on the lithified limestones of the 'White Lias' and Shales-with-Beef.

The nature of the preservation of the borings and burrows observed is dependent not only on the nature of the substrate but also that of the infilling material. Crypts and crypt casts range from poorly defined, irregular shapes infilled with pebbly mudstone to well-defined casts with detailed external ornaments preserved in fine-grained calcareous sandstone.

The Type I crypts and crypt casts are referable to Gastrochaenolites ornatus, produced by a boring bivalve that colonised a firm to hard substrate. We concur with Mikuláš et al. (2003) that this trace fossil cannot be used as a reliable indicator of hard substrates.

Other crypts are more variable in shape and ornamentation and are attributed to more than one type of organism. These include bivalves (including ?Myopholas) and possibly a coelenterate that colonised the substrate above the unconformity surface. These were able to penetrate the already bioturbated and loosened unconformity surface to give rise to irregular-shaped crypts. 
Bioturbation at the sub-Albian unconformity is ubiquitous in southern and eastern England, and indicates that the erosion surface was available for colonisation for a considerable period of time.

More extensive excavation of the unconformity surface, especially at Locality 3 may reveal further information relating to the spatial relationships of the bioturbation structures.

\section{ACKNOWLEDGEMENTS}

We are grateful to landowners for allowing excavation at the Branscombe site; to Richard Edwards for assistance with the excavation and advice; to Radek Mikuláš (Prague), to Markus Bertling (Münster), both of whom provided a pre-publication copy of a coauthored paper; and to Chris Wood who initially suggested the identification of Myopholas. We acknowledge the assistance by Caroline Hensley and Nöel Morris of the Natural History Museum (London) for discussion and demonstrating material, and are indebted to James Watkins and Erica Meller for photographic assistance. We are particularly indebted Simon Kelly, John Pollard and Chris Wood whose reviews of the first draft of the paper resulted in numerous improvements. Roland Goldring died shortly after completing this paper. He will be greatly missed by all those who were fortunate enough to have known him.

\section{References}

Arkell, W. J. 1947. The geology of the country around Weymouth, Swanage, Corfe and Lulworth. Memoirs of the Geological Survey of Great Britain, England and Wales. HMSO, London.

Bertling, M. 1992. Arachnostega n. ichnog. - burrowing traces in internal moulds of boring bivalves (Late Jurassic, Northern Germany). Paläontologisches Zeitschrift, 66, 177-185.

Bromley, R. G. 1996. Trace fossils: Biology, Taphonomy and Applications (2nd edn). Chapman \& Hall, London. 
Bromley, R. G. \& Goldring, R. 1992. The palaeoburrows at the Cretaceous to Palaeocene firmground unconformity in southern England. Tertiary Research, 13, 95-102.

Bromley, R. G. \& Asgaard, U. 1993. Endolithic community replacement on a Pliocene rocky coast. Ichnos, 2, 93-116.

Buck, S. G., \& Goldring, R. 2000. Conical sedimentary structures, trace fossils or not? Observations, experiments and review. Journal of Sedimentary Research, 73, 338353.

Cox, L. R., Newell, N. D., Boyd, D. W., Branson, C. C., Casey, R., Chavan, A., Coogan, H., Dechaseaux, C., Fleming, C. A., Haas, F., Hertlein, L. G., Kauffman, E. G., Keen, A. M., LaRocque, A., McAlester, A. L., Moore, R. C., Nuttall, C. P., Perkins, B. F., Puri, H. S., Smith, L. A., Soot-Ryen, T., Stenzel, H. B., Trueman, E. R., Turner, R. D. \& Weir, J. 1969. Treatise on Invertebrate Paleontology, Part N, Mollusca 6, vols $1 \& 2$. Geological Society of America and University of Kansas. Donovan, D. K. 2002. A new ichnospecies of Gastrochaenolites Leymerie from the Pleistocene Port Morant Formation of southeast Jamaica and the taphonomy of calcareous linings in clavate borings. Ichnos, 9, 61-66.

Evans, J. W. 1970. Palaeontological implications of a biological study of rock-boring clams (Family Pholadidae). In (Crimes, T. P. \& Harper, J. C.; eds) Trace Fossils. Geological Journal Special Issue 3. Seel House Press, Liverpool, 127-140.

Gallois, R. W. 1993. Geology of the country around King's Lynn. Memoirs of the Geological Survey of Great Britain. London: HMSO.

Gallois, R. W. 2001. The lithostratigraphy of the Mercia Mudstone Group (Mid to late Triassic) of the South Devon coast. Geoscience in south-west England, 10, 195-204. Häntschel, W. 1975. Trace fossils and problematica. In (Teichert, C.; ed.) Treatise on Invertebrate Paleontology, Part W, Miscellanea, Supplement 1. Geological Society of America and University of Kansas Press, Boulder, 1-269.

Hamblin R. J. O. \& Wood C. J. 1976. The Cretaceous (Albian-Cenomanian) stratigraphy of the Haldon Hills, south Devon, England. Newsletters in Stratigraphy, 4, 135-149.

Hancock, J. M. 1969. Transgression of the Cretaceous Sea in south-west England. Proceedings of the Ussher Society, 2, 61-83.

Hanken, N-M., Bromley, R. G. \& Thomsen, E. 2001. Trace fossils of the bivalve Panopea faujaci, Pliocene, Rhodes, Greece. Ichnos, 8, 117-130. 
Hesselbo, S. P., Coe, A. L., Batten, D. J. \& Wach, G. D. 1990. Stratigraphic relations of the Lower Greensand (Lower Cretaceous) of the Calne area, Wiltshire. Proceedings of the Geologists' Association, 101, 265-278.

Jensen, S. \& Atkinson, R. J. A. 2001. Experimental production of animal trace fossils, with a discussion of allochthonous trace fossil producers. Neues Jahrbuch für Geologie und Paläontologie, Monatshefte für 2001, 594-606.

Kelly, S. R. A. \& Bromley, R. G. 1984. Ichnological nomenclature of clavate borings. Palaeontology, 27, 793-807.

Mikuláš, R., Nemekova, M., \& Adamovic J. 2002. Bioerosion and bioturbation of a weathered metavolcanic rock (Cretaceous, Czech Republic). Acta Geologica Hispanica, 37, 21-27.

Mikuláš, R., Zitt, J. \& Nekovarik, C. 2003. The ichnogenus Gastrochaenolites and its trace maker from the firmgrounds of the Bohemian Cretaceous Basin (Czech Republic). Ichnos, 10, 15-23.

Pemberton, S. G. \& Frey R. W. 1984. Quantitative methods in ichnology: spatial distribution among populations. Lethaia, 17, 33-49.

Pemberton, S. G., Frey, R. W. \& Bromley, R. G. 1988. The ichnotaxonomy of Conostichus and other plug-shaped ichnofossils. Canadian Journal of Earth Sciences, 25, 866-892.

Pocock, T. I. 1926, The geology of the country around Oxford, Memoir of the Geological Survey of England. HMSO, London.

Röder, H. 1977. Zur Beziehung zwischen Konstruktion und Substrat bei mechanisch bohrenden Bohrmuscheln (Pholadidae, Teredinidae). Senckenbergiana maritima, 9 , 105-213.

Savazzi, E. 1990. Shell biomechanics in the bivalve Laternula. Lethaia, 15, 93-101.

Savazzi, E. 1999. Boring, nestling and tube-dwelling bivalves. In (Savazzi, E.; ed.) Functional Morphology of the Invertebate Skeleton. Wiley: Chichester, 205-237.

Snedden, J. W. 1991. Origin and sequence stratigraphic significance of large dwelling traces in the Escondido Formation (Cretaceous, Texas, USA). Palaios, 6, 541-552.

Trueman , E. R. \& Ansell, A. D. 1969. The mechanics of burrowing into soft substrates by marine animals. Oceanography and Marine Biology, Annual Review, 7, 315-366.

Tucker, M. E. \& Wright, V. P. 1990. Carbonate sedimentology. Blackwell, Oxford.

Uchman, A. \& Wetzel, A. 1999. An aberrant, helicoidal trace fossil Chondrites Sternberg. Palaeogeography, Palaeoclimatology, Palaeoecology, 146, 165-169. 
Gallois, R. W. and Goldring, R. 2007. Albian (Cretaceous) trace fossils. PGA, 118, 265-275.

White, H. J. O. 1921. Short account of the geology of the Isle of Wight. Memoirs of the Geological Survey of Great Britain. London: HMSO.

Woodward H. B. \& Ussher, W. A. E. 1911. The geology of the country near Sidmouth and Lyme Regis (2nd edn). Memoirs of the Geological Survey, England and Wales. London: HMSO.

Worssam, B. C. \& Taylor, J. H. 1969. Geology of the country around Cambridge. Memoirs of the Geological Survey of Great Britain. London: HMSO. 